\title{
Low levels of anti-MPER antibodies are detectable in viremic HIV infected
}

\author{
J Carrillo*, M Massanella, S MArfil, E Garcia, B Clotet, J Blanco \\ From AIDS Vaccine 2012 \\ Boston, MA, USA. 9-12 September 2012
}

\section{Background}

Antibodies against the CD4 binding site (CD4bs) in gp120 and the membrane proximal extracellular region (MPER) of gp41 are associated with broadly neutralization capacity. While the former have been identified in a large number of HIV infected individuals, the latter show a much lower prevalence.

\section{Methods}

31 HIV-infected individuals with detectable viremia were selected for the study. Two samples separated by at least one year were analyzed for each individual. The presence of anti-CD4bs was screened using a competitive flow cytometric assay with a CD4 IgG fusion protein. The presence of anti-MPER antibodies was screened using a sensitive flow cytometric assay that measures antibody binding to different cell lines stably expressing two different truncated forms of gp41. These molecules properly expose the MPER epitope, as assessed by staining with control antibodies 4E10 and 2F5.

\section{Results}

Detectable levels of both anti-CD4bs antibodies and antiMPER antibodies were observed in plasma samples from all groups. Of note, most samples showed recognition of MPER with a strong correlation between the recognition of the two different forms of truncated gp41 used ( $\mathrm{r}=0.65$, $\mathrm{p}<0.0001$ ), suggesting that the assay was robust enough for the detection of these antibodies. However, no correlations were found between the level of anti-MPER antibodies, the neutralizing capacity of plasma samples, the viral load and the CD4 T-cell counts.

IrsiCaixa/HIVACAT, Badalona, Spain

\section{Conclusion}

Anti-MPER antibodies can be detected in viremic chronic HIV infected individuals. The level of these antibodies does not appear to correlate with control of viremia or clinical progression. These data may suggest that anti-MPER antibodies are elicited in the course of HIV infection, but they do not reach the necessary threshold to be easily detectable or to impact infection.

Published: 13 September 2012

doi:10.1186/1742-4690-9-S2-P81

Cite this article as: Carrillo et al:: Low levels of anti-MPER antibodies are detectable in viremic HIV infected. Retrovirology 2012 9(Suppl 2):P81.

\author{
Submit your next manuscript to BioMed Central \\ and take full advantage of: \\ - Convenient online submission \\ - Thorough peer review \\ - No space constraints or color figure charges \\ - Immediate publication on acceptance \\ - Inclusion in PubMed, CAS, Scopus and Google Scholar \\ - Research which is freely available for redistribution \\ Submit your manuscript at \\ www.biomedcentral.com/submit
}

(c) 2012 Carrillo et al; licensee BioMed Central Ltd. This is an Open Access article distributed under the terms of the Creative Commons Attribution License (http://creativecommons.org/licenses/by/2.0), which permits unrestricted use, distribution, and reproduction in any medium, provided the original work is properly cited. 